\title{
Additive Type Affects Fermentation, Aerobic Stability and Mycotoxin Formation during Air Exposure of Early-Cut Rye (Secale cereale L.) Silage
}

\author{
Horst Auerbach ${ }^{1, *(\mathbb{D})}$ and Peter Theobald ${ }^{2}$ \\ 1 International Silage Consultancy, Thomas-Müntzer-Strasse 12, 06193 Wettin-Löbejün, Germany \\ 2 Faculty of Agriculture, Economics and Management, HfWU Nürtingen-Geislingen University, \\ Neckarsteige 6-10, 72622 Nürtingen, Germany; peter.theobald@hfwu.de \\ * Correspondence: horst.uwe.auerbach@outlook.de; Tel.: +49-1520-1683167
}

Received: 28 July 2020; Accepted: 15 September 2020; Published: 21 September 2020

check for updates

\begin{abstract}
Whole-crop rye harvested before maturity represents a valuable forage for silage production. Due to the scarcity of data on fermentation characteristics and aerobic stability (ASTA) and the lack of information on mycotoxin formation during aeration of early-cut rye (ECR) silage after silo opening, we evaluated the effects of different additive types and compositions. Wilted forage was treated with various biological and chemical additives, ensiled in 1.5-L glass jars and stored for 64 days. Fermentation pattern, yeast and mould counts and ASTA were determined at silo opening. In total 34 mycotoxins were analysed in wilted forage and in silage before and after $240 \mathrm{~h}$ of air exposure. Chemical additives caused the lowest dry matter (DM) losses during fermentation accompanied with the lowest ethanol production and the highest water-soluble carbohydrate concentration. Aerobic deterioration, which started within two days after silo opening in silage left untreated and inoculated with homofermentative lactic acid bacteria, was prevented by the combined use of heteroand homofermentative lactic acid bacteria and the chemical additive containing sodium nitrite, hexamethylene tetramine and potassium sorbate. Moreover, these two additives largely restricted the formation of the mycotoxin roquefortine $\mathrm{C}$ to $<0.05 \mathrm{mg} \mathrm{kg}^{-1} \mathrm{DM}$ after aeration, whereas untreated silage contained $85.2 \mathrm{mg} \mathrm{kg}^{-1} \mathrm{DM}$.
\end{abstract}

Keywords: aerobic stability; aerobic deterioration; early-cut rye; fermentation; moulds; mycotoxins; roquefortine $C$; silage additives; yeasts

\section{Introduction}

Early-cut winter rye (ECR, Secale cereale L.) has been widely used for decades as a silage crop in Germany, especially in the eastern regions, and hybrids specifically bred for forage production have become available. Along with triticale, rye cut early before maturity has very recently attracted attention in other European countries, e.g., Hungary [1]. Although it is also grown as cover crop between cash crops [2], it is mainly used as forage for silage production in double-cropping systems with maize [3], but cultivation as a summer catch crop has been increasing [4]. The early harvest, which at the latest takes place just before flowering, enables farmers to grow two crops per year, which is usually maize after winter rye and summer rye after cereals or rape seed, thereby increasing land productivity $[3,5]$. Double-cropping increases nutrient cycling within the farm and reduces the amount of imported feed reducing negative environmental impacts [3].

With increasing stages of maturity, the dry matter (DM) yield increases [1], whereas a marked decline in the nutritive value is observed by rapid plant development [4]. The optimal stage of maturity is largely determined by the dietary requirements of the animals to which ECR silage is 
fed. Despite typically high sugar concentrations in ECR at harvest exceeding $100 \mathrm{~g} \mathrm{~kg}^{-1} \mathrm{DM}[1,6,7]$, fermentation quality can be poor, as reflected by acetic acid concentrations of up to $84.2 \mathrm{~g} \mathrm{~kg}^{-1} \mathrm{DM}$, butyric acid concentrations of up to $25.2 \mathrm{~g} \mathrm{~kg}^{-1} \mathrm{DM}$, and by ammonia-N levels of up to $230 \mathrm{~g} \mathrm{~kg}^{-1}$ of the total $\mathrm{N}$ concentration (Table 1). Analytical results on the nutritive value of ECR silage, which were produced on commercial German dairy farms and analysed by the accredited feed analysis laboratory, LKS mbH, Niederwiesa, Germany, are presented in Table 1.

Table 1. Nutritive value and fermentation characteristics $\left(\mathrm{g} \mathrm{kg}^{-1}\right.$ dry matter (DM), unless stated otherwise) of early-cut rye silages analysed in 2016-2018 by LKS mbH, Niederwiesa, Germany.

\begin{tabular}{|c|c|c|c|c|c|}
\hline Parameter & $\mathbf{n}$ & Mean & SD & Minimum & Maximum \\
\hline Dry matter, $\mathrm{g} \mathrm{kg}^{-1}$ & 657 & 281 & 61 & 172 & 584 \\
\hline Crude ash & 657 & 75 & 19 & 29 & 166 \\
\hline Crude protein & 657 & 129 & 27 & 53 & 225 \\
\hline Crude fibre & 657 & 287 & 37 & 186 & 425 \\
\hline ADL & 657 & 30 & 10 & 3 & 70 \\
\hline Sugar* & 657 & 36 & 38 & 0 & 230 \\
\hline Metabolisable energy, $\mathrm{MJ} \mathrm{kg}^{-1} \mathrm{DM}$ & 657 & 10.6 & 0.7 & 7.9 & 12.0 \\
\hline Net-Energy-Lactation, MJ NEL kg ${ }^{-1} \mathrm{DM}$ & 657 & 6.4 & 0.5 & 4.5 & 7.5 \\
\hline $\mathrm{pH}$ & 559 & 4.2 & 0.4 & 3.3 & 5.3 \\
\hline Ammonia-N, $\mathrm{g} \mathrm{kg}^{-1}$ total $\mathrm{N}$ ) & 657 & 86 & 29 & 19 & 230 \\
\hline Lactic acid & 52 & 75.9 & 45.8 & 4.1 & 152.2 \\
\hline Acetic acid $\ddagger$ & 52 & 25.9 & 21.9 & 2.6 & 84.2 \\
\hline Butyric acid $^{\dagger}$ & 52 & 1.4 & 5.1 & 0 & 25.2 \\
\hline
\end{tabular}

SD, standard deviation; ADL, acid-detergent lignin; DM, dry matter; ${ }^{*}$ sum of glucose, fructose and saccharose; $\ddagger$ sum of acetic and propionic acids, ${ }^{\dagger}$ sum of n-butyric, iso-butyric, n-valeric, iso-valeric and n-caproic acids; 0 denotes values below detection limit.

To our knowledge, data on fungal contamination of fresh and ensiled ECR is very limited [6,7]. The increase in temperature caused by aerobic yeast and mould metabolism is known to cause not only losses in DM, but also to lead to indirect losses due to lower nutritive value, reduced feed intake and animal performance [8,9]. Moreover, a range of mycotoxins produced by moulds have been detected in several silage types produced under laboratory and commercial farm conditions [10-13], but no data is available on ECR. These toxic fungal metabolites may negatively affect the health of farm animals [13-15]. Depending on storage conditions regarding the availability of air, a succession of the mycoflora takes place, which is also affected by climatic conditions, leading to significant differences in silage mould populations between regions [16]. In temperate climates, the most prominent field fungi, e.g., Fusarium and Alternaria, disappear quickly after anaerobiosis has been reached [17], whereas other moulds survive the fermentation process and can grow and produce mycotoxin after silo opening [18]. Penicillium roqueforti (sensu lato), which consists of three distinctive species-P. roqueforti, P. carneum and P. paneum $[19,20]$, Monascus ruber and Aspergillus fumigatus—are most commonly found in several silage types in temperate climate $[10,12,21,22]$.

In addition to the well-known management principles of producing good silage, silage additives have been used to improve the fermentation process and to alleviate the detrimental effects of air on silage quality during the feed-out phase. Biological and chemical additives differ in their mode of action and are used depending on the desired effect, either to improve fermentation quality or aerobic stability, or both $[23,24]$. Although there is an overwhelming number of articles on the effects of additives used in crops like lucerne, clover, grass, maize, whole-crop cereals and small grains, systematic studies on their effects in ECR are limited [6,7], comprising a total of only five published trials testing only a small range of potential silage additive types. Therefore, the aim of our study was to deepen the knowledge on fermentation characteristics, fungal populations, aerobic stability and mycotoxin formation in silage produced from ECR stored under challenging conditions with short fermentation length and air infiltration during storage. Moreover, the effects of biological and 
chemical additives of different composition were evaluated to determine potential candidates ensuring consistently high silage quality under farm conditions for further investigation. We hypothesised that fermentation pattern, fungal populations, and aerobic stability (ASTA) can be altered by silage additives in accordance with their expected mode of action, and that the prevention of aerobic deterioration will result in the suppression of mycotoxin formation by moulds during feed-out.

\section{Materials and Methods}

\subsection{Ensiling}

The leafy-type rye (Secale cereale L., cv. Protector, Saatenunion, Isernhagen, Germany), which was specifically bred for forage production, was sown at $3 \times 10^{6}$ seeds ha ${ }^{-1}$ on 11 September 2016, on a dairy farm in Klein Schulzendorf, Germany (52.1949552 N-13.250923 W). Prior to seeding, the field received $\mathrm{N}$ fertilizer exclusively from cattle slurry at a rate of $60 \mathrm{~kg} \mathrm{ha}^{-1}$. In early March 2017, additional N $\left(80 \mathrm{~kg} \mathrm{~N} \mathrm{ha}^{-1}\right)$ was applied in form of a mixture of ammonium carbonate and ammonium nitrate. Rye was cut on the morning of 10 May 2017 and wilted overnight before it was chopped by a precision chopper (Krone, Big X 650) set at $30 \mathrm{~mm}$ theoretical particle length. Equal quantities of forage (50 kg) from three different field locations with a distance between them of about $100 \mathrm{~m}$ were taken and thoroughly mixed to form a composite sample to minimize potential effects of sampling location on silage variables due to different forage composition [25], which may interfere with the effects of the tested additives.

Before manual packing of the forage into 1.5-L glass jars (Weck, Öfingen, Germany), the forage was divided into five piles. After suspending and diluting, respectively, of the products with tap water, the following additives (provided by KONSIL Europe GmbH, Wettin-Löbejün, Germany) were applied at a rate of $10 \mathrm{~mL} \mathrm{~kg}^{-1}$ wilted forage: no additive (tap water, $\mathrm{CON}$ ), homofermentative lactic acid bacteria $\left(\mathrm{LAB}_{\mathrm{ho}}\right)$ composed of Lactobacillus plantarum DSM 16,627 and Lactobacillus paracasei NCIMB 30,151 (total inoculation rate: $1.5 \times 10^{5} \mathrm{cfu} \mathrm{g}^{-1}$ ), combination of hetero- and homofermentative lactic acid bacteria ( $\mathrm{LAB}_{\text {heho }}$ ) composed of Lactobacillus buchneri CNCM-I 4323 and Pediococcus acidilactici DSM 11,673 (total inoculation rate: $1.67 \times 10^{5} \mathrm{cfu}^{-1}$ ), liquid chemical mixture (SNHE) containing sodium nitrite $\left(300 \mathrm{~g} \mathrm{~L}^{-1}\right)$ and hexamethylene tetramine $\left(200 \mathrm{~g} \mathrm{~L}^{-1}\right)$, applied at $2 \mathrm{~mL} \mathrm{~kg}^{-1}$, or a liquid chemical blend (SNHEPS) containing sodium nitrite $\left(195 \mathrm{~g} \mathrm{~L}^{-1}\right)$, hexamethylene tetramine $\left(71 \mathrm{~g} \mathrm{~L}^{-1}\right)$ and potassium sorbate $\left(106 \mathrm{~g} \mathrm{~L}^{-1}\right)$, added at $2 \mathrm{~mL} \mathrm{~kg}^{-1}$. The jars had a 6-mm hole in the lid and in the body, which were closed by rubber stoppers. Along with the intentionally low packing density of $87 \mathrm{~kg} \mathrm{DM} \mathrm{m}^{-3}$, the removal of the rubber stoppers on day 28 and day 57 of storage for $24 \mathrm{~h}$ aimed at creating challenging test conditions by allowing air to penetrate and freely circulate through the silage mass, thereby stimulating fungal development. According to Jungbluth et al. (2017), packing density affected the gas exchange, reaching the oxygen concentration of air $(21 \%, v / v)$ much faster in low density than in high density silage [26]. Experimental silages were prepared in triplicate for each treatment and were stored for 64 days in a dark room, whose temperature was set at $21^{\circ} \mathrm{C}$.

\subsection{Dry Matter Determination}

The DM content of forage and silage was determined by oven-drying at $60^{\circ} \mathrm{C}$ until a constant weight was achieved, followed by $3 \mathrm{~h}$ of drying at $105^{\circ} \mathrm{C}$ [27]. Silage DM content was corrected for the loss of volatiles during drying [27]. The losses of DM during fermentation were calculated as described by Weissbach [28].

\subsection{Chemical and Microbiological Analysis}

All samples for chemical analyses ( $\mathrm{pH}$, ammonia- $\mathrm{N}$, acids and alcohols, water-soluble carbohydrates) were stored at $-18^{\circ} \mathrm{C}$ until use. Nutrient composition and energy concentration were determined by the accredited laboratory LKS $\mathrm{mbH}$, Niederwiesa, Lichtenwalde on oven-dried $\left(60^{\circ} \mathrm{C}\right.$, $24 \mathrm{~h}$ ) samples by using the official methods for feed evaluation [29] and energy estimation [30] in 
Germany. Buffering capacity (BC, given in g lactic acid $\left.\mathrm{kg}^{-1} \mathrm{DM}\right)$ was analysed by titration of dried forage samples $\left(60^{\circ} \mathrm{C}, 24 \mathrm{~h}\right)$ with lactic acid to $\mathrm{pH} 4.0$. Finally, the fermentability coefficient (FC) was calculated using the equation by Schmidt et al. [31]: FC $=\mathrm{DM} \mathrm{[ \% ]}+8 \times \mathrm{WSC} / \mathrm{BC}$, where WSC is the concentration of water soluble-carbohydrates (WSC) and BC is the buffering capacity.

Extracts of fresh silage were prepared by blending $50 \mathrm{~g}$ of sample with $200 \mathrm{~mL}$ of distilled water to which $1 \mathrm{~mL}$ toluene was added. After storage overnight at $4{ }^{\circ} \mathrm{C}$, the extracts were filtered through a paper filter, followed by microfiltration $(0.45 \mu \mathrm{m})$. Volatile fatty acids and alcohols were analysed by GC with flame-ionization detection according to Weiss et al. [32], whereas lactic acid was determined by HPLC coupled with a refractive index detector [33]. Silage $\mathrm{pH}$ was measured potentiometrically by using a $\mathrm{pH}$ electrode, and a colorimetric method based on the Berthelot-reaction (CFA, Scan++, Skalar Analytical, Breda, The Netherlands) was used to determine ammonia-N concentration. The concentration of WSC (mainly composed of glucose, fructose, disaccharides and fructosans) was determined after extraction of fresh silage samples in cold water for one hour, subsequent addition of anthrone reactant (composed of anthrone, thiourea and sulphuric acid) and subsequent spectro-photometrical analysis [34].

Serial dilutions of fresh forage and silage samples were prepared in $0.1 \%(w / w)$ peptone water broth. Lactic acid bacteria (LAB) were counted by pour-plating and incubation for four days on MRS (De Man, Rogosa and Sharpe) medium at $30{ }^{\circ} \mathrm{C}$ [35]. Yeasts and moulds were enumerated by spread-plating on yeast extract-dextrose-chloramphenicol agar after incubation for three to five days at $25^{\circ} \mathrm{C}$ [36]. The total fungal count was calculated by summing up the number of individual yeast and mould colonies grown on the plates.

\subsection{Aerobic Stability Measurement}

As described by Honig [37], the ASTA of silage was evaluated based on the temperature development in the samples compared with that of the room, which was kept at $20.6 \pm 0.2{ }^{\circ} \mathrm{C}$. Data loggers (Tinytag Talk 2, Gemini, Chichester, UK) were placed in the geometric centre of a plastic container which was loosely filled with silage. The data loggers recorded silage and room temperature at 2-h intervals. Each plastic container was stored in an insulating polystyrene box, allowing free air circulation for $240 \mathrm{~h}$. Silage was considered aerobically unstable once its temperature had increased by $2{ }^{\circ} \mathrm{C}$ above ambient temperature. To assess the extent of aerobic deterioration (AD), the cumulated temperature (TCUM) was calculated by summing up the temperature differences between silage and room [38]. The original procedure was modified by changing the interval of data recording from one hour to two hours.

\subsection{Mycotoxin Analysis}

Silage mycotoxin analyses were performed in the fresh forage before ensiling and in the silage on the day of silo opening and after $240 \mathrm{~h}$ of air exposure in treatments CON, LAB heho and SNHEPS only. These were selected based on the results from the test for aerobic stability ensuring large treatment differences. Silage samples were stored at $-18{ }^{\circ} \mathrm{C}$ until analysis, which was carried out by RIKILT Wageningen University and Research, The Netherlands, using an accredited and validated multi-species (34 mycotoxins) LC/MS-MS method. This method can detect fungal metabolites produced by the major forage and silage moulds, including the genera Fusarium, Alternaria, Penicillium, Aspergillus. From each sample, $2.5 \mathrm{~g}$ were weighed in a $50 \mathrm{~mL}$ plastic tube and $7.5 \mathrm{~mL}$ of water, $10 \mathrm{~mL}$ of extraction solvent (acetonitrile/acetic acid, 99:1, v/v), and $25 \mu \mathrm{L}$ of 13C-caffeine internal standard (IS) were added. The tubes were shaken manually to disperse the sediments on the bottom of the tube and put in a 'head-over-head' extracting device (Heidolph Reax 2, Schwabach, Germany) for $30 \mathrm{~min}$. Subsequently, $4 \mathrm{~g}$ of magnesium sulphate were added and the tubes vortexed for $1 \mathrm{~min}$, followed by centrifugation at $3000 \mathrm{rpm}$ for $10 \mathrm{~min}$ and transfer of $200 \mu \mathrm{L}$ of sample extract to polypropylene vials (Whatmann syringeless filter device). After the addition of $200 \mu \mathrm{L}$ of water, each vial was capped and shaken in a vortex mixer (for approximately $3 \mathrm{~s}$ ). After storage in the refrigerator $\left(4^{\circ} \mathrm{C}\right.$ ) for $30-60 \mathrm{~min}$, the vials were closed with a pressing device (Six Position Compression; Whatman's-Hertogenbosch, The Netherlands) and stored 
at $4{ }^{\circ} \mathrm{C}$ until analysis. Mycotoxin determinations were performed using an LC-MS/MS (Waters Acquity, Etten-Leur, The Netherlands, AB SCIEX QTRAP ${ }^{\circledR}$ 6500, Applied Biosystems, Nieuwekerk aan de IJssel, The Netherlands) with a Restek Ultra Aqueous $\mathrm{C}_{18} 3 \mu \mathrm{m} 100 \times 2.1 \mathrm{~mm}$ UPLC column (Restek Corporation, Bellefonte, USA) and a sample injection volume of $5 \mu \mathrm{L}$. The gradient was performed using two different eluents: eluent $A$ consisted of $1 \mathrm{mM}$ ammonium formate and $1 \%(v / v)$ formic acid in water; eluent $B$ consisted of $1 \mathrm{mM}$ ammonium formate and $1 \%(v / v)$ formic acid in a mix of methanol and water 95:5 $(v / v)$. Eluent $C$ consisted of $5 \mathrm{mM}$ ammonium acetate and $0.1 \%(v / v)$ acetic acid in water; eluent $\mathrm{D}$ contained $5 \mathrm{mM}$ ammonium acetate and $0.1 \%(v / v)$ acetic acid in a mix of methanol and water 95:5 (v/v). Eluent A and B were used when analysing mycotoxins in positive mode (ESI+), whereas eluent $C$ and $D$ were used when detecting mycotoxins in negative mode (ESI-). Each mycotoxin was identified by its retention time and the peak area ratio between two transitions. Quantification was performed by a single point standard addition protocol. Calibration curves were linear with coefficients of determination of $R^{2} \geq 0.994$. The limit of quantification was equal to the lowest validated mycotoxin concentration and varied between mycotoxins. Average recoveries ranged between $80-120 \%$, except those for DON-3-glucoside (73\%), nivalenol $(73 \%)$, citrinin (121\%) and moniliformin (125\%).

\subsection{Statistical Analysis}

All data were analysed as a completely randomized design by the Faculty of Life Sciences, Department of Biometry and Agricultural Experimentation, Humboldt Universität zu Berlin, Germany, using the software package of SAS, version 9.4, (Cary, NC, USA). Treatments were compared in a framework of a fixed effects model using silage additive as experimental factor with three replications: $y_{\mathrm{ij}}=\mu+\alpha_{\mathrm{i}}+\varepsilon_{\mathrm{ij}}$, where $\mathrm{y}_{\mathrm{ij}}$ is the observed value of the $\mathrm{jth}$ replication from silage additive $\mathrm{i} ; \mu$ the population mean; $\alpha_{\mathrm{i}}$ the fixed effect of silage additive $\mathrm{i}$; and $\mathrm{e}_{\mathrm{ij}}$ the random residual effect of the ith treatment and jth observation, $\sim \mathrm{N}\left(0, \sigma^{2}\right.$ e). For silage mycotoxin analyses upon silo opening and after air exposure, a two-factorial fixed effects model with three replications was used: $y_{i j k}=\mu+\alpha_{i}+\beta_{j}+(\alpha \beta)_{i j}+\varepsilon_{i j k}$, where $y_{i j k}$ is the observed value of the kth replication from silage additive $i$ and aeration treatment $j ; \mu$ the population mean; $\alpha_{i}$ the fixed effect of silage additive $i, \beta_{j}$ the fixed effect of aeration treatment $j$, and $\mathrm{e}_{\mathrm{jk}}$ the random residual effect of the ijth treatment and $\mathrm{jth}$ observation, $\sim \mathrm{N}\left(0, \sigma^{2}{ }_{e}\right)$.

After checking the assumption of normally distributed residuals by Shapiro-Wilk-Test and graphical diagnostics, traits for which normality of observations could be assumed were subjected to ANOVA, whereas a non-parametric rank procedure using an ANOVA-type statistics was employed for non-normally distributed data (procedure MIXED). When significance was detected $p<0.05$ in the global $F$ test, pairwise comparisons among means were performed followed by Tukey's test or by pair-wise rank tests. Pair-wise differences among means were considered significant at $p<0.05$, and a tendency to significance was declared at $0.05 \leq p \leq 0.10$. The procedure REG was used to characterise the relationships between silage variables. The best-fit regression model at $p<0.05$ was selected based on the root mean square error (RMSE) and the coefficients of determination $\left(R^{2}\right)$, which was adjusted for degrees of freedom.

\section{Results}

\subsection{Wilted Forage}

The chemical and microbiological characteristics of the forage prior to ensiling before additive application are presented in Table 2. Wilted and chopped ECR had a DM concentration of $250 \mathrm{~g} \mathrm{~kg}^{-1}$. It contained $188 \mathrm{~g} \mathrm{WSC} \mathrm{kg}^{-1} \mathrm{DM}$ and $326 \mathrm{~g}$ crude fibre $\mathrm{kg}^{-1} \mathrm{DM}$. The fermentability coefficient (FC) was calculated to be 60 . Yeast and mould populations were present at $\geq \log _{10} 5.0 \mathrm{cfu} \mathrm{g}^{-1}$. None of the 34 mycotoxins, which could be detected by the employed method, were found. 
Table 2. Composition of wilted forage before additive application $\left(n=3\right.$, data given in $\mathrm{g} \mathrm{kg}^{-1} \mathrm{DM}$ unless stated otherwise).

\begin{tabular}{|c|c|c|}
\hline Parameter & Mean & Standard Deviation \\
\hline Dry matter, g/kg & 250 & 1.4 \\
\hline Crude ash & 56 & 0.4 \\
\hline Crude protein & 101 & 2.4 \\
\hline Crude fibre & 326 & 9.4 \\
\hline Sugar * & 166 & 1.6 \\
\hline Water-soluble carbohydrates $^{\dagger}$ & 188 & 1.3 \\
\hline Buffering capacity, g lactic acid $\mathrm{kg}^{-1} \mathrm{DM}$ & 43 & 0.7 \\
\hline Fermentability coefficient & 60 & 0.4 \\
\hline Metabolizable energy, $\mathrm{MJ} \mathrm{kg}^{-1} \mathrm{DM}$ & 9.6 & 0.1 \\
\hline Net-Energy-Lactation, MJ NEL kg ${ }^{-1}$ DM & 5.7 & 0 \\
\hline Lactic acid bacteria, $\log _{10} \mathrm{cfu} \mathrm{g}^{-1}$ & 5.9 & 0.2 \\
\hline Yeasts, $\log _{10} \mathrm{cfu} \mathrm{g}^{-1}$ & 5.3 & 0.1 \\
\hline Moulds, $\log _{10} \mathrm{cfu} \mathrm{g}^{-1}$ & 5.0 & 0.6 \\
\hline Total fungi, $\log _{10} \mathrm{cfu} \mathrm{g}^{-1}$ & 5.5 & 0.3 \\
\hline
\end{tabular}

${ }^{*}$ sum of glucose, fructose and saccharose; ${ }^{\dagger}$ sum of sugar and fructans.

\subsection{Silage}

Additive application had an effect on all tested silage parameters (Table 3). When compared with untreated silage, both chemical additives and $\mathrm{LAB}_{\mathrm{ho}}$ reduced $\mathrm{DM}$ loss during fermentation whereas $\mathrm{LAB}_{\text {heho }}$ application resulted in an increase $(p<0.001)$. The lowest $\mathrm{pH}(p<0.001)$ was associated with the highest lactic acid concentration in $\mathrm{LAB}_{\text {ho }}$ treated silage $(p<0.001)$. The use of $\mathrm{LAB}_{\text {heho }}$ stimulated acetic acid production, whereas application of $\mathrm{LAB}_{\text {ho }}$ caused the lowest concentration $(p<0.001)$. Ethanol formation was largely suppressed by both chemical additives $(p<0.001)$. Propionic acid and n-propanol were only detected in silage left untreated or inoculated with $\mathrm{LAB}_{\text {heho, }}$ with the latter treatment containing larger concentrations of both substances $(p<0.001)$. Except $\mathrm{LAB}_{\text {heho, }}$ additives had no influence on 1,2-propanediol production $(p<0.001)$. Both chemical additives preserved the largest concentrations of WSC of all treatments $(p<0.001)$. The counts of yeasts $(p<0.05)$ and moulds $(p<0.01)$ were highest in treatments $\mathrm{CON}$ and $\mathrm{LAB}_{\text {ho }}$, and the application of $\mathrm{LAB}_{\text {heho }}$ and SNHEPS resulted in fungal counts below the detection limit.

Untreated and $\mathrm{LAB}_{\mathrm{ho}}$-inoculated silage spoiled rapidly upon air exposure after $65 \mathrm{~h}$, which was accompanied by an increase in TCUM to 285 and $308^{\circ} \mathrm{C}$, respectively (Figure 1). Adding $L A B_{\text {heho }}$ or SNHEPS maintained silage stability over the entire period of aeration $(p<0.01)$ and largely restricted the extent of aerobic deterioration, as reflected by lower TCUM values $(p<0.001)$. A tendency was observed for an improvement of ASTA by SNHE use compared with untreated silage $(p=0.059)$.

There was a strong linear, positive relationship between the concentration of ethanol and DM losses during fermentation $\left(\mathrm{R}^{2}=0.89\right.$, RMSE $\left.=0.44, p<0.001\right)$. Regressing the DM losses on the total concentration of ethanol and n-propanol also showed a close linear, positive relationship $\left(R^{2}=0.96\right.$, RMSE $=0.27, p<0.001$ ), and the additional inclusion of 1,2-propanediol into the model further improved the coefficient of determination of the relationship to $\mathrm{R}^{2}=0.99$ (Supplementary Materials, Figure S1, RMSE $=0.11, p<0.001)$. The counts of yeasts and moulds upon silo opening were strongly positively correlated $\left(R^{2}=0.80\right.$, RMSE $\left.=0.46, p<0.001\right)$, and the ASTA highly depended on the numbers of yeasts (linear relationship, $\mathrm{R}^{2}=0.77, \mathrm{RSME}=0.31, p<0.001$ ) and moulds (linear relationship, $\mathrm{R}^{2}=0.95$, RSME $=0.14, p<0.001)$. However, the best-fit was obtained by regressing aerobic stability on total fungal counts (Figure $2, \mathrm{R}^{2}=0.98$, RMSE $=0.09, p<0.001$ ). A weak, negative logarithmic relationship existed between the concentration of acetic acid and the ASTA $\left(R^{2}=0.43\right.$, RMSE $\left.=62.6, p<0.01\right)$. As presented in Figure 3, aerobic stability and the extent of aerobic deterioration as expressed as TCUM were very closely correlated and best described by a polynomial function $\left(R^{2}=0.96\right.$, RMSE $\left.=27.2, p<0.001\right)$. 
Table 3. Effects of additive type and composition on dry matter (DM) losses, fermentation characteristics and fungal populations of early-cut rye silage stored for 64 days (data presented as LSmeans in $\mathrm{g} \mathrm{kg}^{-1}$ DM unless stated otherwise, $n=3$ ).

\begin{tabular}{|c|c|c|c|c|c|c|c|}
\hline Parameter & CON & $\mathrm{LAB}_{\text {ho }}$ & LAB $_{\text {heho }}$ & SNHE & SNHEPS & SEM & $p$ \\
\hline DM loss, $\%$ & $7.0^{\mathrm{c}}$ & $6.4^{b}$ & $9.4^{\mathrm{d}}$ & $5.9^{\mathrm{a}}$ & $5.9^{\mathrm{a}}$ & 0.03 & $<0.001$ \\
\hline $\mathrm{pH}$ & $4.08^{b}$ & $3.96^{\mathrm{a}}$ & $4.33^{\mathrm{d}}$ & $4.31^{\mathrm{d}}$ & $4.12^{\mathrm{c}}$ & 0.007 & $<0.001$ \\
\hline Lactic acid & $78.4^{\mathrm{d}}$ & $89.0^{\mathrm{e}}$ & $39.5^{\mathrm{a}}$ & $57.0^{\mathrm{b}}$ & $66.4^{\mathrm{c}}$ & 0.60 & $<0.001$ \\
\hline Acetic acid & $19.5^{b}$ & $15.5^{\mathrm{a}}$ & $52.7^{c}$ & $18.8^{a b}$ & $20.6^{b}$ & 0.81 & $<0.001$ \\
\hline Propionic acid & $0.3^{y}$ & $0^{x}$ & $4.1^{\mathrm{z}}$ & $0^{x}$ & $0^{x}$ & $0-0.31$ & $<0.001$ \\
\hline Ethanol & $8.6^{c}$ & $6.9^{b}$ & $13.9^{\mathrm{d}}$ & $2.2^{\mathrm{a}}$ & $2.3^{a}$ & 0.24 & $<0.001$ \\
\hline n-propanol & $0.5^{\mathrm{y}}$ & $0^{x}$ & $3.9^{\mathrm{z}}$ & $0^{x}$ & $0^{x}$ & $0-0.42$ & $<0.001$ \\
\hline 1,2-propanediol & $2.9^{a}$ & $2.2^{\mathrm{a}}$ & $24.0^{\mathrm{b}}$ & $1.3^{\mathrm{a}}$ & $1.2^{\mathrm{a}}$ & 0.93 & $<0.001$ \\
\hline Ammonia- $\mathrm{N}, \mathrm{gkg}^{-1}$ total $\mathrm{N}$ & $26^{\mathrm{ab}}$ & $24^{\mathrm{a}}$ & $33^{c}$ & $32^{c}$ & $30 \mathrm{bc}$ & 0.9 & $<0.001$ \\
\hline WSC * & $15.2^{\mathrm{a}}$ & $20.1^{\mathrm{ab}}$ & $11.2^{\mathrm{a}}$ & $59.2^{\mathrm{c}}$ & $36.9^{b}$ & 4.12 & $<0.001$ \\
\hline Yeast count, $\log _{10} \mathrm{cfu} \mathrm{g}^{-1}$ & $3.6^{y}$ & $3.6^{y}$ & $<2.0^{\mathrm{x}}$ & $<2.0^{x}$ & $<2.0^{x}$ & $0-0.39$ & $<0.05$ \\
\hline Mould count, $\log _{10} \mathrm{cfu} \mathrm{g}^{-1}$ & $4.0^{\mathrm{z}}$ & $3.6^{\mathrm{yz}}$ & $<2.0^{x}$ & $2.5^{\mathrm{y}}$ & $<2.0^{x}$ & $0-0.25$ & $<0.01$ \\
\hline
\end{tabular}

CON, no additive; $\mathrm{LAB}_{\mathrm{ho}}$, homofermentative inoculant composed of L. plantarum DSM 16,627 and L. paracasei NCIMB, total inoculation rate: $1.5 \times 10^{5} \mathrm{cfu} \mathrm{g}^{-1}$; $\mathrm{LAB}_{\text {heho, }}$, inoculant composed of L. buchneri CNCM-I 4323 and $P$. acidilactici DSM 11,673, total inoculation rate: $1.67 \times 10^{5} \mathrm{cfu}^{-1}$; SNHE, liquid chemical additive containing sodium nitrite $\left(300 \mathrm{~g} \mathrm{~L}^{-1}\right)$ and hexamethylene tetramine $\left(200 \mathrm{~g} \mathrm{~L}^{-1}\right), 2 \mathrm{~mL} \mathrm{~kg}^{-1}$; SNHEPS, liquid chemical additive containing sodium nitrite $\left(195 \mathrm{~g} \mathrm{~L}^{-1}\right)$, hexamethylene tetramine $\left(71 \mathrm{~g} \mathrm{~L}^{-1}\right)$ and potassium sorbate $\left(106 \mathrm{~g} \mathrm{~L}^{-1}\right), 2 \mathrm{~mL} \mathrm{~kg}^{-1}$; * WSC, water-soluble carbohydrates; ${ }^{\mathrm{a}-\mathrm{e}}$ values in rows bearing unlike superscripts differ at $p<0.05$, Tukey's test; ${ }^{x-z}$ values in rows bearing unlike superscripts differ at $p<0.05$, non-parameteric rank test of ANOVA-type statistics, SEM of non-normally distributed data was calculated separately for each treatment.

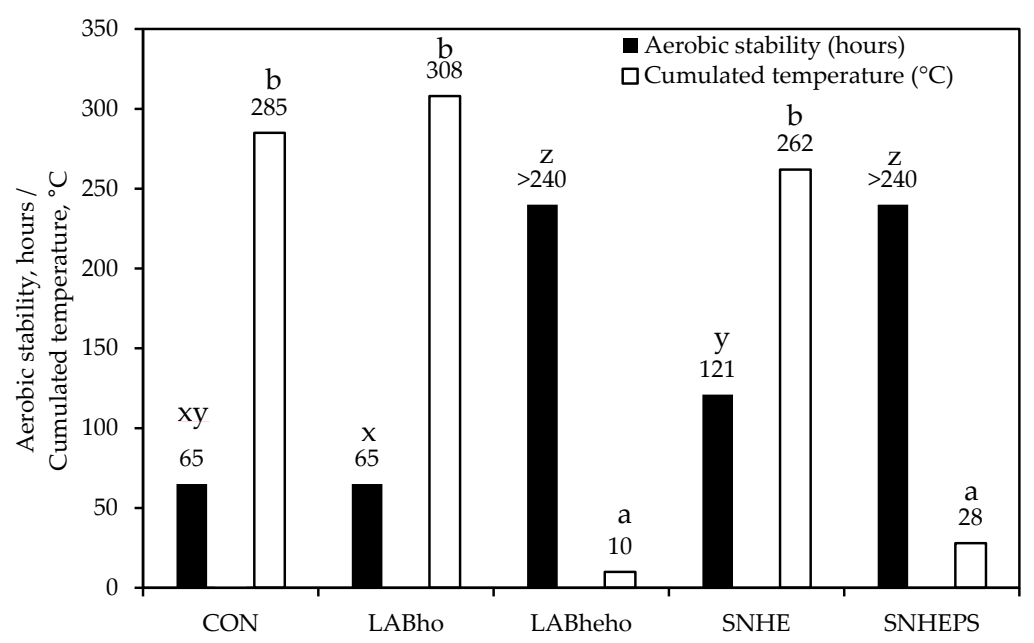

Figure 1. Effects of additive type and composition on the aerobic stability (ASTA) and the cumulated temperature (TCUM) in early-cut rye silage after 64 days of storage. $\mathrm{CON}$, no additive; $\mathrm{LAB}_{\text {ho, }}$ homofermentative inoculant composed of L. plantarum DSM 16,627 and L. paracasei NCIMB, total

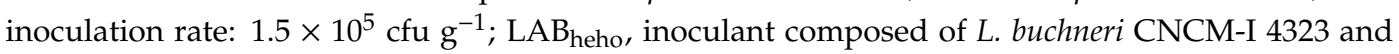
$P$. acidilactici DSM, total inoculation rate: $1.67 \times 10^{5} \mathrm{cfu} \mathrm{g}^{-1}$; SNHE, liquid chemical additive containing sodium nitrite $\left(300 \mathrm{~g} \mathrm{~L}^{-1}\right)$ and hexamethylene tetramine $\left(200 \mathrm{~g} \mathrm{~L}^{-1}\right), 2 \mathrm{~mL} \mathrm{~kg}^{-1}$; SNHEPS, liquid chemical additive containing sodium nitrite $\left(195 \mathrm{~g} \mathrm{~L}^{-1}\right)$, hexamethylene tetramine $\left(71 \mathrm{~g} \mathrm{~L}^{-1}\right)$ and potassium sorbate $\left(106 \mathrm{~g} \mathrm{~L}^{-1}\right), 2 \mathrm{~mL} \mathrm{~kg}^{-1}$; >denotes that ASTA was greater than $240 \mathrm{~h}^{\text {; }}{ }^{\mathrm{a}-\mathrm{b}}$ open bars for TCUM bearing different superscripts differ, Tukey's test, $p<0.001, \mathrm{SEM}=17.2{ }^{\mathrm{x}-\mathrm{z}}$ solid bars for ASTA with unlike superscripts differ, non-parameteric rank test of ANOVA-type statistics, $p<0.01$, $\mathrm{SEM}=0-13.7$, calculated separately for each treatment due to non-normal data distribution, $n=15$. 


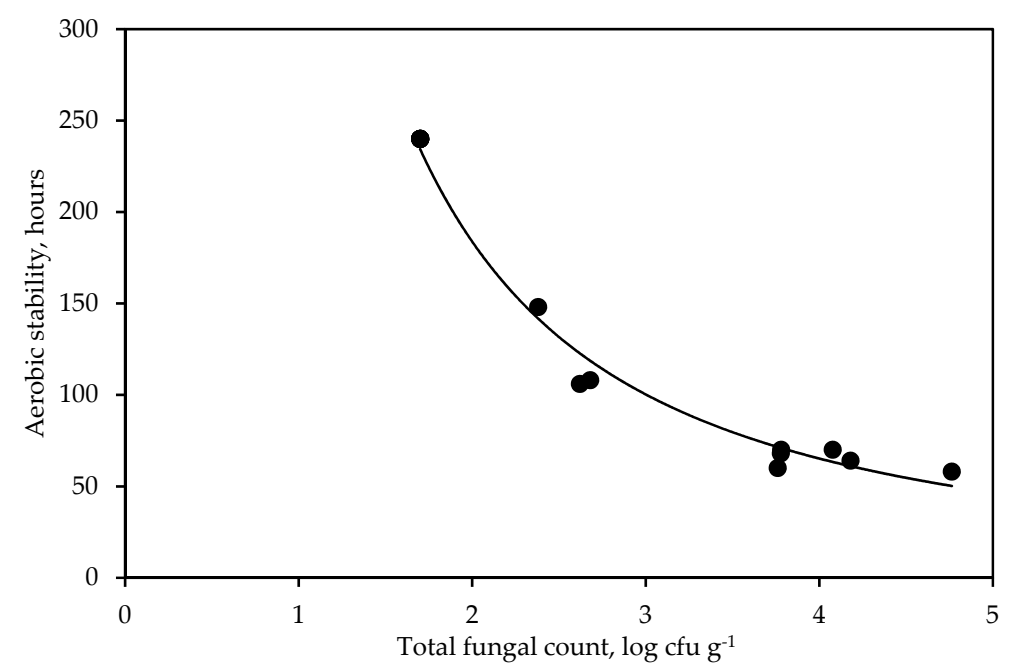

Figure 2. Relationship between the total fungal count at silo opening ( $x$ ) and the aerobic stability (y) in early-cut rye silage treated with additives of different type and composition and stored for 64 days upon subsequent air exposure for $240 \mathrm{~h} . \mathrm{R}^{2}=0.98$, root mean square error (RMSE) $=0.09, p<0.001$, $n=15$.

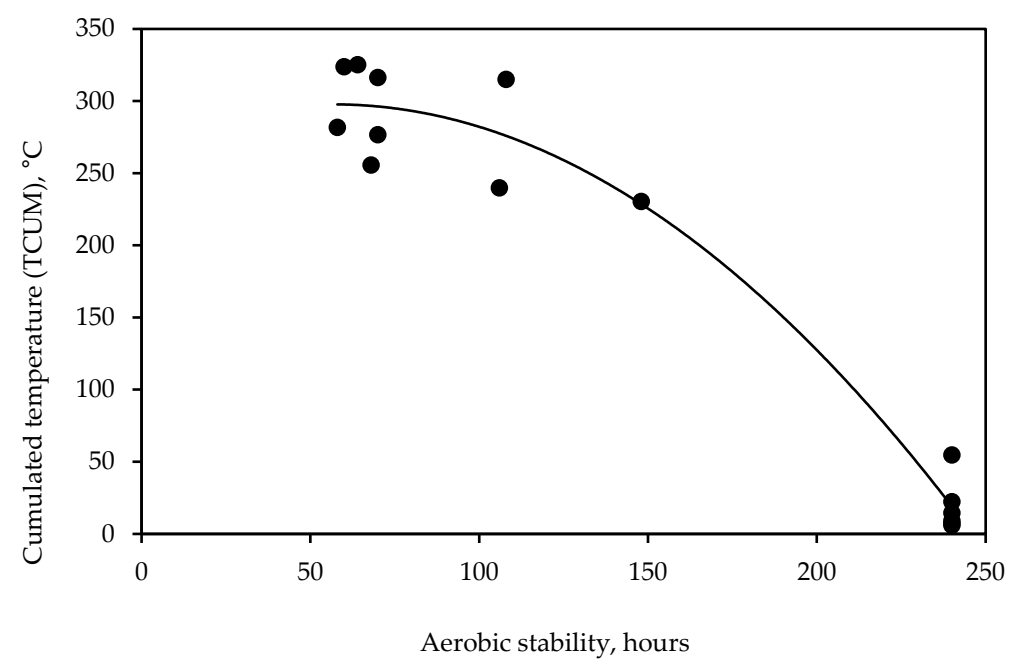

Figure 3. Relationship between the aerobic stability $(x)$ and the cumulated temperature (y) in early-cut rye silage treated with additives of different type and composition and stored for 64 days upon subsequent air exposure for $240 \mathrm{~h} . \mathrm{R}^{2}=0.96, \mathrm{RMSE}=27.2, p<0.001, n=15$.

\subsection{Mycotoxin Formation}

Roquefortine $\mathrm{C}$ was the only mycotoxin detected in ECR silage at silo opening. The results given in Figure 4 demonstrate that untreated silage contained this mycotoxin already before air exposure $\left(0.20 \mathrm{mg} \mathrm{kg}^{-1} \mathrm{DM}\right)$, whereas the tested additives completely inhibited mycotoxin formation during storage $(p<0.001)$. During subsequent exposure to air, roquefortine $C$ concentrations generally increased $(p<0.001)$ but they were much larger in untreated $\left(85.2 \mathrm{mg} \mathrm{kg}^{-1} \mathrm{DM}\right)$ than in treated $\left(0.04 \mathrm{mg} \mathrm{kg}^{-1} \mathrm{DM}\right)$ ECR silage $(p<0.001)$ at the end of aeration. 


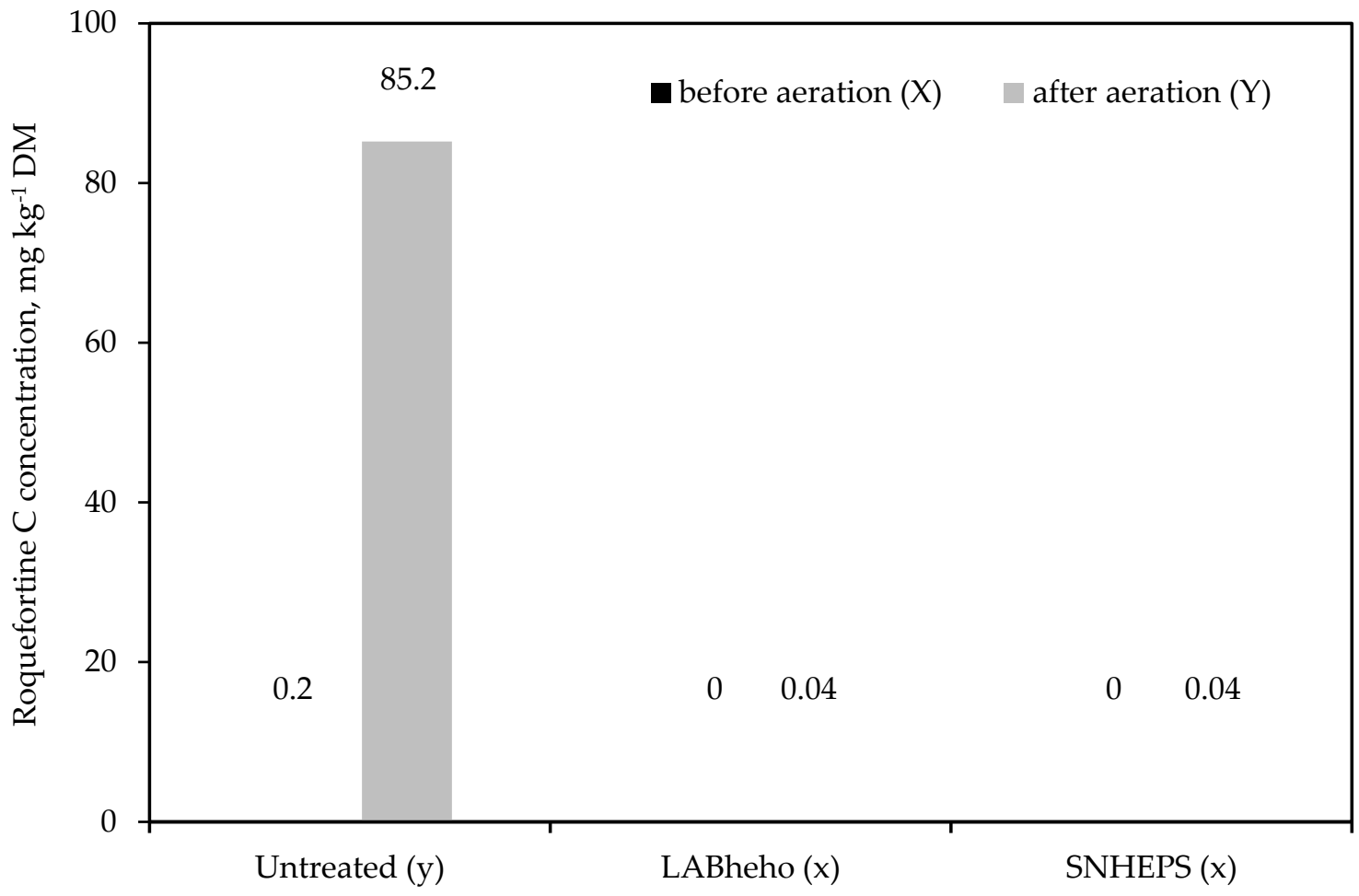

Figure 4. Effects of additive type on the concentration of the mycotoxin roquefortine $\mathrm{C}$ in early-cut rye silage stored for 64 days before (black bar) and after (grey bar) subsequent air exposure for $240 \mathrm{~h}$.

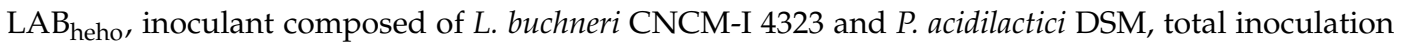
rate: $1.67 \times 10^{5} \mathrm{cfu} \mathrm{g}^{-1}$; SNHEPS, liquid chemical additive containing sodium nitrite $\left(195 \mathrm{~g} \mathrm{~L}^{-1}\right)$, hexamethylene tetramine (71 $\left.\mathrm{g} \mathrm{L}^{-1}\right)$ and potassium sorbate $\left(106 \mathrm{~g} \mathrm{~L}^{-1}\right), 2 \mathrm{~mL} \mathrm{~kg}^{-1}$; Unlike letters in brackets denote significance of effect of aeration $(X, Y, p<0.001)$ and of effect of additive $(x, y$, $p<0.001$ ), aeration $\times$ additive interaction not significant, ANOVA-type statistics, SEM $=0-8.79$, calculated separately for each treatment due to non-normality of data.

\section{Discussion}

\subsection{Wilted Forage}

The DM content at ensiling was similar to that shown by Auerbach et al. [7] and corresponded well with the average DM content of $281 \mathrm{~g} \mathrm{~kg}^{-1}$ found in ECR silage from commercial dairy farms in Germany (Table 1). The concentration of crude fibre was higher and crude protein content was lower than reported earlier [1,7], highlighting the influence of the stage of maturity at harvest [4]. Concomitantly, energy concentrations were much lower than previously observed [7].

The forage contained large quantities of sugar and water-soluble carbohydrates, respectively, which agrees with previous findings [6,7]. On this account, and due to low buffering capacity, the ECR could be classified as easy-to-ensile [39], reflecting a low risk of poor fermentation quality in the silage produced from it. However, Bader [6] reported lower FC values ranging between 29 and 35, which was mainly due to using direct-cut ECR of low DM content. The yeast count represented a typical value of above $10^{5} \mathrm{cfu} \mathrm{g}^{-1}$ for ECR [7] or for whole-crop wheat cut at flowering [40].

None of the 34 detectable mycotoxins were found in ECR at ensiling. This may be explained by the early harvest, giving moulds not enough time to infest the plant, and produce mycotoxins. It was shown for maize and wheat that the concentrations of mycotoxins produced by Fusarium species in the field increased with progressing length of vegetation [41,42]. 


\subsection{Fermentation Characteristics and Aerobic Deterioration}

The DM losses during fermentation in untreated silage agree with those previously reported [6,7]. According to Borreani et al. [8], DM losses of as low as 5\% DM caused by in-silo respiration, fermentation and effluent production can be expected under good management conditions on farms. However, the available data on DM losses in ECR silage produced in laboratory silos have consistently been higher than this threshold value (7.0 to 9.1\%) [6,7], highlighting the prominent role of specific fermentation pathways involved and substrates used. Production of butyric acid by clostridia and ethanol formation by yeasts result in the highest DM losses [43]. In our study, no butyric acid was found, which can be attributed to the high FC of 60 , and a sufficiently large epiphytic LAB population $\left(>10^{5} \mathrm{cfu}^{-1}\right)$ on the forage at ensiling. According to Weissbach and Honig [39], silage was particularly prone to clostridial fermentation when forages contained less than $10^{5} \mathrm{LAB} \mathrm{g}^{-1}$ and $0.5 \mathrm{~g}$ nitrate $\mathrm{kg}^{-1} \mathrm{DM}$. In their study on different forages $(n=244)$, including ECR, $78 \%$ of the produced silages contained butyric acid,

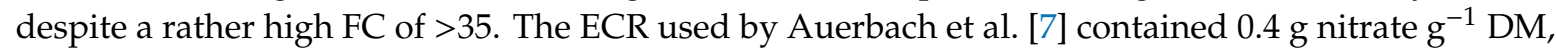
leading to the formation of butyric acid $\left(1.5 \mathrm{~g} \mathrm{~kg}^{-1} \mathrm{DM}\right)$, whereas in three out of four trials by Bader [6], ECR silages contained no butyric acid despite low FC. This can be attributed to high nitrate levels above $2.5 \mathrm{~g} \mathrm{~kg}^{-1} \mathrm{DM}$. On the contrary, high butyric acid concentrations were detected in the fourth study $\left(>10 \mathrm{~g} \mathrm{~kg}^{-1} \mathrm{DM}\right)$, which used forage comparably low in nitrate $\left(0.7 \mathrm{~g} \mathrm{~kg}^{-1} \mathrm{DM}\right)$ and epiphytic LAB $\left(<10^{4} \mathrm{cfu} \mathrm{g}^{-1}\right)$.

Lactic and acetic acids and ethanol concentration were in the range typical for grass silage at 25 to 35\% DM [44] and confirmed earlier results [7]. However, ECR silage may contain much higher concentrations of these fermentation end-products, especially when DM at ensiling is low resulting in excessive fermentation intensity [6]. The comparison of WSC concentrations determined in the fresh forage at ensiling and in the silage revealed that $>90 \%$ was utilized during fermentation, which agrees with data by Auerbach et al. [7], reporting a decline in WSC from $173 \mathrm{~g} \mathrm{~kg}^{-1} \mathrm{DM}$ at ensiling to $24 \mathrm{~g} \mathrm{~kg}^{-1}$ DM after 91 days of fermentation.

An improvement in the efficiency of the fermentation process as reflected by lower DM losses was

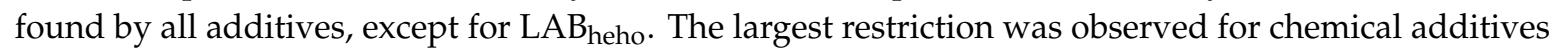
regardless of their composition. This substantiates earlier findings showing a reduction in DM loss by 0.8 percentage units by the use of homofermentative $\mathrm{LAB}$, and by 2.1 percentage units by application of a chemical blend having the same composition as treatment SNHE in our study [6]. Moreover, inoculation with homofermentative LAB also decreased DM loss by 2.9 percentage units in the study by Auerbach et al. [7], in which chemical additives were not tested. Our data on ECR silage are in general agreement with the results of a meta-analysis on the use of homofermentative and facultative heterofermentative $L A B$ in various silage types [45]. These authors detected a significant improvement in $\mathrm{DM}$ recovery in grass and legume silages by homofermentative $\mathrm{LAB}$. The combined use of $\mathrm{LAB}_{\text {heho }}$ increased DM loss in ECR silage, as was previously reported by Auerbach et al. [7] for the sole use of heterofermentative LAB of the L. buchneri-type. This is in line with observations by Kleinschmit and Kung [46] stating lower DM recovery in grass and small grain silage inoculated with this additive type.

Obviously, the additives used in our study differently affected microbial populations and their production of $\mathrm{CO}_{2}$, which is the main source of DM losses during fermentation [47,48]. Inoculation with $\mathrm{LAB}_{\text {ho }}$ resulted in a more homolactic fermentation, leading to the lowest $\mathrm{pH}$ of all treatments [7] but, in general, the differences between treatments were of no biological and practical relevance. The most significant change in fermentation pattern was observed in $\mathrm{LAB}_{\text {heho }}$ silage, as reflected by very high acetic acid concentrations and the lowest content of lactic acid [7]. The low DM at ensiling may have caused intensive metabolic activity of L. buchneri, supporting recent data by Gomes et al. [49], who determined higher acetic acid contents in direct-cut than in wilted whole-crop oat silage. Obviously, L. buchneri, which can anaerobically degrade lactic acid to acetic acid, and 1,2-propanediol [50] dominated the fermentation in our trial. The concentration of 1,2-propanediol in $\mathrm{LAB}_{\text {heho }}$ silage was highest compared with all other treatments but still only about $60 \%$ of the quantity determined earlier [7]. Thus, large variations regarding this parameter between trials can be expected. The presence 
of 1,2-propanediol in all treatments other than $\mathrm{LAB}_{\text {heho, }}$ including $\mathrm{CON}$, may be explained by the presence of wild, epiphytic $L$. buchneri strains on the forage at ensiling, but their numbers and metabolic activity, respectively, must have been lower because this compound was detected at small quantities only. In agreement with Bader [6], the chemical additives proved their potential to largely restrict ethanol production with no differences between them. Moreover, $\mathrm{LAB}_{\text {ho }}$ application reduced ethanol production when compared with untreated silage at similar magnitude as reported by Bader [6] and Oliveira et al. [45]. On the contrary, $\mathrm{LAB}_{\text {heho }}$ stimulated ethanol formation, which is attributable to the capacity of obligately and facultatively heterofermentative LAB also to produce alcohol, depending on sugar type and metabolic pathway [43]. Our results agree with other reports on substantially increased ethanol level in grass and small grain silage by L. buchneri treatment [46]. The lack of response to L. buchneri-inoculation in ECR regarding ethanol production described by Auerbach et al. [7] may be associated with the strictly anaerobic storage, whereas air infiltration was allowed in our study. It is known that air can alter sugar utilization by LAB leading to different metabolic end-products [51]. The proportion of ethanol originating from yeast metabolism can be considered insignificant as in treatments $\mathrm{LAB}_{\text {heho, }}$ SNHE and SNHEPS yeast numbers were below the detection limit upon silo opening, and no differences were observed between untreated and $\mathrm{LAB}_{\mathrm{ho}}$-inoculated silage. However, data on the accumulation pattern during storage were not recorded. The synthesis of the n-propanol and propionic acid was totally suppressed in treatments LAB $_{\text {ho, }}$ SNHE and SNHEPS, but most likely by different mechanisms. Although it can also be produced by yeasts [43], its presence in silage is most commonly associated with the activity of L. diolivorans, which utilizes 1,2-propandiol to form equimolar quantities of propionic acid and n-propanol under anoxic conditions [52]. Recently, Zielinska et al. [53] also demonstrated 1,2-propanediol-degrading capabilities of L. reuteri and L. buchneri strains but the conversion efficiency was much poorer than that of L. diolivorans, and there is no data yet available on the occurrence of $L$. reuteri in a silage environment. The added $\mathrm{LAB}_{\mathrm{ho}}$ may have outcompeted the epiphytic L. diolivorans population, whereas we assume that the chemical additives suppressed this species directly. Additionally, storage length may affect 1,2-propanediol conversion, as described by Auerbach and Nadeau [54] using the same $\mathrm{LAB}_{\text {heho }}$ product and the same chemical additive SNHEPS in grass-clover silage of 35\% DM. More so, Gomes et al. [49] showed an effect of DM at ensiling on L. diolivorans activity demonstrating limited osmotolerance of this species. Despite the same total concentration of the three compounds involved in its unique metabolic pathway in untreated and L. buchneri-inoculated silage, direct-cut oat silage had much higher concentrations of $\mathrm{n}$-propanol and propionic acid and contained less 1,2-propanediol than detected in silage from wilted forage.

Both chemical additives preserved more WSC during fermentation when compared with untreated or $\mathrm{LAB}_{\text {heho }}$ silage. This strongly suggests a direct inhibitory effect on sugar-utilizing microbial populations during storage.

The differences in the counts of yeasts between untreated and $\mathrm{LAB}_{\mathrm{ho}}$-inoculated silage and $\mathrm{LAB}_{\text {hohe }}$ application can be ascribed to different acetic acid concentrations. This compound has been repeatedly shown to reduce silage yeast numbers $[7,46]$, and the magnitude of the effect strongly depended on the acetic acid content. However, this observation cannot explain the lower yeast counts in silages treated with chemical additives due to similarly high acetic acid concentrations detected in untreated silage. According to Woolford [55], sodium nitrite has very limited activity against yeasts, leading us to conclude that hexamethylene tetramine, and even more so the inclusion of the potent antimycotic agent potassium sorbate [56,57], caused their complete elimination. Untreated silage and that inoculated with $\mathrm{LAB}_{\mathrm{ho}}$ had the highest mould count whereas this population was not detected in treatments $\mathrm{LAB}_{\text {heho }}$ and SNHEPS. Typically, moulds die off soon after anaerobiosis has been attained [58], and only a few species can survive in an anaerobic silage environment $[17,18]$. The number of moulds on forages can vary significantly depending on location, but they are frequently near or below the detection limit in silage after extended storage length $[57,59]$. In our study, however, air was allowed to penetrate twice during storage, which likely caused the survival and growth of moulds, leading to visible signs of mould infestation already upon silo opening in untreated silage and 
those inoculated with $\mathrm{LAB}_{\mathrm{ho}}$. The reason for the lack of response in ASTA to homolactic inoculation, which frequently reduced aerobic stability in ECR silage $[6,7,60]$ may be attributable to similar fungal counts, comparable concentrations of WSC and acetic acid, and the generally fast onset of aerobic deterioration when compared with untreated silage. When L. buchneri, applied alone or in combination with homofermentative $\mathrm{LAB}$, dominated the fermentation process resulting in higher acetic acid concentrations, aerobic stability was improved $[46,47,61]$. In agreement with observations by Auerbach and Nadeau [9] on increased stability by using the chemical additive SNHEPS, this effect should mainly be attributed to the antimycotic action of potassium sorbate contained in the additive. This also explains why this product outperformed treatment SNHE without this substance. The tendency towards better aerobic stability by SNHE than that of untreated silage was likely caused by the antifungal properties of hexamethylene tetramine [55].

\subsection{Relationships between Silage Variables}

In our study, DM losses during fermentation were largely affected by the concentrations of ethanol alone, or the sum of ethanol and n-propanol substantiating previous results by Auerbach et al. [47] on whole-crop rye silage harvested at dough stage $\left(R^{2}=0.86, p<0.001\right)$, by Weiss et al. [62] on maize silage $\left(R^{2}=0.70, p<0.001\right)$, and data from a meta-analysis by Rabelo et al. [47] on sugarcane silage $\left(R^{2}\right.$ not given, $p<0.01$ ). This highlights the prominent role of ethanol and other silage alcohols regarding the release of $\mathrm{CO}_{2}$, which always results in significant DM losses, regardless of the metabolic pathway and the microbial population producing it.

The power of the linear relationship between the counts of yeasts and moulds upon silo opening confirmed data on maize silage $\left(\mathrm{R}^{2}=0.75\right)$ by Teller et al. [56]. On the contrary, Schmidt and Kung [59] detected a much weaker degree of correlation $\left(R^{2}=0.12\right)$. This highlights the role other factors may have on the degree of correlation between yeast and mould counts, e.g., forage, location, storage length, number and composition of the epiphytic mycoflora, and the succession pattern during storage.

The strong negative correlations between acetic acid content and ASTA reported by Kleinschmit and Kung [46] $\left(R^{2}=0.66\right)$ and by Auerbach et al. [7] $\left(R^{2}=0.85\right)$ could not be confirmed by our results. Their evaluations exclusively considered untreated silage, or silage inoculated with heterofermentative LAB alone or in combination with homofermentative LAB. However, in our study, the reduction of yeast numbers in the chemical treatments was mainly caused by the used chemicals with antifungal properties, including hexamethylene tetramine, and potassium sorbate because only minor effects on acetic acid content existed. This also explains why the detected relationship between acetic acid concentration and aerobic stability was weaker than that previously found in ECR silage $\left(R^{2}=0.88\right)$ by Auerbach et al. [7], or by Schmidt and Kung [59] in maize silage $\left(R^{2}=0.95\right)$. Omission of the values from silage treated with the potassium sorbate-containing additive SNHEPS improved the coefficient of determination to $\mathrm{R}^{2}=0.86(p<0.001)$ in our study.

We found similar characteristics of the function describing the relationship between yeast count and aerobic stability to previous findings $\left(\mathrm{R}^{2}=0.85, p<0.01\right)$ [7]. However, as a better-fit model was found when aerobic stability was regressed on mould count, we assume mould activity had played a more substantial role in the spoilage process than yeasts, which were typically considered the main causative fungal population to initiate aerobic deterioration [63].

The increase in aerobic stability was associated with a lower extent of aerobic deterioration as reflected by TCUM and substantiate data by Auerbach and Nadeau [9] on grass and grass-clover silage. However, the type and power of the relationship can differ widely between studies because silage may rapidly heat-up upon air exposure but at different rates depending on additive use and application rate and amount and type of utilizable substrate to support and sustain fungal growth $[57,64,65]$. This leads us to suggest the parameter TCUM be more suitable to characterise and predict potential changes in nutritive value during aeration $[9,38]$. However, type and slope of the regression function may vary widely between studies because of different test conditions. Frequently, like in our study, the tests for 
ASTA are terminated before silages of all treatments become aerobically unstable, thereby exerting a significant impact on the regression function.

\subsection{Mycotoxin Formation}

The low concentration of roquefortine $\mathrm{C}$ found in untreated silage before air exposure confirmed results from laboratory ensiling experiments by Auerbach [18] using maize silage. Like in our trial, air ingress was enabled to stimulate mould growth, and mycotoxin formation, but the aeration protocol was different. Roquefortine $C$, which has been detected in numerous studies in temperate climates $[10,22,66]$, was very likely produced by two representatives of the P. roqueforti-group frequently found in silage, P. roqueforti and P. paneum $[10,20,67]$ although mould identification was not performed in our study. In addition to other species, e.g., P. expansum [67], these two representatives were shown to synthesise roquefortine $C$, whereas the third species, P. carneum, lacked this capacity [19]. The high incidence of species of the $P$. roqueforti-group in silage can be explained by its good adaptation to acidic environments and to anaerobic or micro-aerophilic conditions [68]. The detected roquefortine C quantities in untreated ECR silage ( $\left.>85 \mathrm{mg} \mathrm{kg}^{-1} \mathrm{DM}\right)$ were much higher than those reported in the literature for other silages, e.g., grass and maize silage $[10,69]$. This may be explained by the extent of mould growth in the samples because differences were frequently observed between visibly moulded and unmoulded silage $[10,70]$. In our study, untreated silage was completely decomposed after $240 \mathrm{~h}$ of aeration.

Our hypothesis was not confirmed to detect metabolites other than roquefortine $C$, which can be produced by the P. roqueforti-group, e.g., mycophenolic acid, patulin, penicillic acid, PR toxin. These have been found in grass and maize silage $[22,69,70]$, and co-occurrence with roquefortine $C$ has been observed $[69,71]$. Even if PR toxin had been formed, it could not have been detected by the employed method. Penicillic acid may be produced by P. carneum whose incidence in silage seems to be low $[19,20]$. However, other factors may have played an important role, too. According to Müller and Amend [70], the length of exposure to air affected mycotoxin synthesis, and the formed quantities. An extended period of aeration of $>13$ days had elapsed to the first detection of mycophenolic and penicillic acids, which was longer than the length of air exposure in our study. Moreover, these authors found the concentrations of all mycotoxins, including PR toxin, to peak and thereafter decline to below the detection limit. This was explained by the low stability of certain mycotoxins at high $\mathrm{pH}$ values that are typical in deteriorated silage, and by possible interactions with ammonia or amino acids, rendering the parent compound undetectable. These reactions have not been described for roquefortine $\mathrm{C}$. Moreover, depletion of carbon sources for mould growth and mycotoxin production rates lower than that of their disappearance may have contributed to our results. Thus, mycotoxin formation and accumulation pattern are affected by numerous factors, including the presence and the metabolic activity of the producing mould species, silage type, available carbon sources and length of exposure to air. As expected, the tested silage additives largely restricted the formation of roquefortine $C$ in ECR silage. This supports observations by Auerbach [18] on roquefortine $C$ formation in maize silage by benzoic acid, and by Cavallarin et al. on aflatoxin production in corn silage exposed to air for 7 days by a heterofermentative inoculant [72]. Whenever mould growth is restricted or inhibited upon exposure to air, mycotoxin biosynthesis is delayed and completely prevented, respectively.

\section{Conclusions}

Low DM rye harvested before maturation was well fermented but deteriorated rapidly upon exposure to air. The dual-purpose inoculant composed of L. buchneri and P. acidilactici and the chemical additive containing sodium nitrite, hexamethylene tetramine and potassium sorbate, ensured long-lasting protection against aerobic instability caused by fungal microorganisms. The production of the mycotoxin roquefortine $C$ during air exposure was largely restricted by the use of these additives. In conclusion, the use of biological and chemical additives preventing changes in silage quality upon 
exposure to air is encouraged but further studies are warranted to determine the additive type which is best suited to consistently ensure high quality of silage made from early-cut rye.

Supplementary Materials: The following are available online at http:/www.mdpi.com/2073-4395/10/9/1432/s1, Figure S1: Relationship between the total concentration of ethanol + n-propanol + 1,2-propanediol (x) at silo opening and the dry matter (DM) losses during fermentation (y) in early-cut rye silage treated with additives of different types and compositions after 64 days of storage. $R^{2}=0.99$, RMSE $=0.11, p<0.001, n=15$.

Author Contributions: Conceptualization, H.A. and P.T.; methodology, H.A. and P.T.; software, P.T. and H.A.; validation H.A. and P.T.; formal analysis, B.K.; investigation, P.T. and H.A.; resources, P.T. and H.A.; data curation, H.A. and P.T.; writing — original draft preparation, H.A.; writing-review and editing, P.T. and H.A.; visualization, P.T. and H.A.; supervision, P.T.; project administration, P.T. and H.A.; funding acquisition, H.A. and P.T. All authors have read and agreed to the published version of the manuscript.

Funding: This research was primarily funded by the University Nürtingen-Geislingen, Germany and the International Silage Consultancy (ISC), Germany. Additional minor funding was provided by the KONSIL Europe $\mathrm{GmbH}$, Germany.

Acknowledgments: We are deeply indebted to B. Kroschewski, Humboldt Universität zu Berlin, Germany for data processing and running statistical analyses of this trial. We greatly acknowledge the support by Kirsten Weiss, Humboldt University, Berlin, Germany, for analysing fermentation pattern, and W. Richardt, LKS mbH, Lichtenwalde, Germany, for providing data on nutritional and fermentation quality of ECR silage produced on commercial farms in Germany. We would also like to thank H. van Egmont and T. de Rijk, RIKILT Wageningen University and Research, The Netherlands, for mycotoxin analysis.

Conflicts of Interest: Horst Auerbach and Peter Theobald are holding shares in the company KONSIL Europe $\mathrm{GmbH}$, which provided the tested additives.

\section{Abbreviations}

ASTA, aerobic stability; AD, aerobic deterioration; DM, dry matter; ECR, early-cut rye; LAB, lactic acid bacteria; RMSE, root mean square error; TCUM, cumulated temperature; WSC, water-soluble carbohydrates.

\section{References}

1. Orosz, S.; Kruppa, J.; Kruppa, J., Jr.; Szemethy, D.; Piskerne Fülöp, E.; Futo, Z.; Hoffmann, R. Harvest window: Comparison of whole crop rye and whole crop triticale in an early cut system. In Proceedings of the XVIII International Silage Conference, Bonn, Germany, 24-26 July 2018; Gerlach, K., Südekum, K.-H., Eds.; University of Bonn: Bonn, Germany, 2018; pp. 516-517.

2. Everett, L.A.; Wilson, M.L.; Pepin, R.R.; Coulter, J.A. Winter rye cover crop with liquid manure injection reduces spring soil nitrate but not maize yield. Agronomy 2019, 9, 852. [CrossRef]

3. Ranck, E.J.; Holden, L.A.; Dillon, J.A.; Rotz, C.A.; Soder, K.J. Economic and environmental effects of double cropping winter annuals and corn using the Integrated Farm System Model. J. Dairy Sci. 2020, 103, 3804-3815. [CrossRef]

4. Jeroch, H.; Flachowsky, G.; Weissbach, F. Futtermittelkunde, 1st ed.; Gustav Fischer Verlag: Jena, Germany, 1993; pp. 74-154.

5. Tabacco, E.; Comino, L.; Borreani, G. Production efficiency, costs and environmental impacts of conventional and dynamic forage systems for dairy farms in Italy. Eur. J. Agron. 2018, 99, 1-12. [CrossRef]

6. Bader, S. Möglichkeiten zur Steuerung des Gärungsverlaufes bei der Grünfuttersilierung durch kombinierte Anwendung biologischer und chemischer Zusätze (Possibilities to control the course of fermentation of forages by the combined use of biological and chemical additives). Landbauforsch. Völkenrode 1997, 176, 1-110. 
7. Auerbach, H.; Weiss, K.; Theobald, P.; Nadeau, E. Effects of inoculant type on dry matter losses, fermentation pattern, yeast count and aerobic stability of green rye silages. In Proceedings of the 12. BOKU-Symposium Tierernährung, Vienna, Austria, 11 April 2013; Mair, C., Kraft, M., Wetscherek, W., Schedle, K., Eds.; University of Natural Resources and Life Sciences: Vienna, Austria, 2013; pp. 179-185.

8. Borreani, G.; Tabacco, E.; Schmidt, R.J.; Holmes, B.J.; Muck, R.E. Silage review: Factor affecting dry matter and qualitative losses in silages. J. Dairy Sci. 2018, 101, 3952-3979. [CrossRef]

9. Auerbach, H.; Nadeau, E. Effects of additive type on fermentation characteristics, yeast count and aerobic stability and changes in nutritive value of grass silage exposed to air. Agronomy 2020, 10, 1229. [CrossRef]

10. Auerbach, H.; Oldenburg, E.; Weissbach, F. Incidence of Penicillium roqueforti and roquefortine $\mathrm{C}$ in silages. J. Sci. Food Agric. 1998, 76, 565-572. [CrossRef]

11. Schneweis, I.; Meyer, K.; Hoermansdorfer, S.; Bauer, J. Mycophenolic acid in silage. Appl. Environm. Microbiol. 2000, 66, 3639-3641. [CrossRef]

12. Scudamore, K.A.; Livesey, C.T. Occurrence and significance of mycotoxins in forage crops and silage: A review. J. Sci. Food Agric. 1998, 77, 1-17. [CrossRef]

13. Ogunade, I.M.; Martinez-Tuppia, C.; Queiroz, O.C.M.; Jiang, Y.; Drouin, P.; Wu, F.; Vyas, D.; Adesogan, A.T. Silage review: Mycotoxins in silage: Occurrence, effects, prevention, mitigation. J. Dairy Sci. 2018, 101, 4034-4059. [CrossRef] [PubMed]

14. Fink-Gremmels, J. Mycotoxins in cattle feeds and carry-over to dairy milk: A review. Food Add. Contam. 2008, 25, 172-180. [CrossRef] [PubMed]

15. Gallo, A.; Giuberti, G.; Bertuzzi, T.; Moschini, M.; Masoero, F. Study on the effects of PR toxin, mycophenolic acid and roquefortine $C$ on in vitro gas production parameters and their stability in the rumen environment. J. Agric. Sci. 2015, 153, 163-176. [CrossRef]

16. Alonso, V.A.; Pereyra, C.M.; Keller, L.A.M.; Dalcero, A.M.; Rosa, C.A.R.; Chiaccheria, S.M.; Cavaglieri, L.R. Fungi and mycotoxins in silage: An overview. J. Appl. Microbiol. 2013, 115, 637-643. [CrossRef]

17. Pelhate, J. Maize silage: Incidence of moulds during conservation. Folia Vet. Lat. 1977, 7, 1-16. [PubMed]

18. Auerbach, H. Mould growth and mycotoxin contamination of silages: Sources, types and solutions. In Nutritional Biotechnology in the Feed and Food Industries, Proceedings of Alltech's Nineteenth Annual Symposium, Lexington, KY, USA, 13-14 May 2003; Jacques, K., Lyons, T.P., Eds.; Nottingham University Press: Nottingham, UK, 2003; pp. 247-265.

19. Boysen, M.E.; Jacobsson, K.-G.; Schnürer, J. Molecular identification of species from the Penicillium roqueforti group associated with spoiled animal feed. Appl. Environ. Microbiol. 2000, 66, 1523-1526. [CrossRef]

20. O’Brien, M.; Nielsen, K.F.; O'Kiely, P.; Forristal, P.D.; Fuller, H.T.; Frisvad, J.C. Mycotoxins and other metabolites produced in vitro by Penicillium paneum Frisvad and Penicillium roqueforti Thom isolated from baled grass silage in Ireland. J. Agric. Food Chem. 2006, 54, 9268-9276. [CrossRef]

21. Meyer, K.; Ostertag, J.; Richter, W.; Spiekers, H.; Bauer, J. Toxins from Aspergillus fumigatus in silages. In Proceedings of the XVth International Silage Conference, Madison, WI, USA, 27-29 July 2009; Broderick, G.A., Adesogan, A.T., Bocher, L.W., Bolsen, K.K., Contreras-Govea, F.E., Harrison, J.H., Muck, R.E., Eds.; University of Wisconsin-Madison: Madison, WI, USA, 2009; pp. 159-160.

22. McElhinney, C.; Danahert, M.; Elliott, C.T.; O'Kiely, P. Mycotoxins in farm silages-A 2-year Irish national survey. Grass Forage Sci. 2015, 71, 1-14. [CrossRef]

23. Kung, L., Jr.; Stokes, M.R.; Lin, C.J. Silage additives. In Silage Science and Technology; Agronomy Series 42; Buxton, D.R., Muck, R.E., Holmes, H.J., Eds.; American Society of Agronomy, Inc. Publishers: Madison, WI, USA, 2003; pp. 305-360.

24. Muck, R.E.; Nadeau, E.M.G.; McAllister, T.A.; Contreras-Govea, F.E.; Santos, M.C.; Kung, L., Jr. Silage review: Recent advances and future uses of silage additives. J. Dairy Sci. 2018, 101, 3980-4000. [CrossRef]

25. Kroschewski, B.; Auerbach, H.; Weiss, K. Statistics and experimental design in silage research: Some comments on design and analysis of comparative silage experiments. In Proceedings of the XVIII International Silage Conference, Bonn, Germany, Germany 24-26 July 2018; Gerlach, K., Südekum, K.-H., Eds.; University of Bonn: Bonn, Germany, 2018; pp. 554-560.

26. Jungbluth, K.H.; Trimborn, M.; Maack, G.-C.; Büscher, W.; Li, M.; Cheng, H.; Cheng, Q.; Sun, Y. Effects of three additives and two bulk densities on maize silage characteristics, temperature profiles, $\mathrm{CO}_{2}$ and $\mathrm{O}_{2}$-dynamics in small scale silos during aerobic exposure. Appl. Sci. 2017, 7, 545. [CrossRef] 
27. Weissbach, F.; Strubelt, C. Correcting the dry matter content of grass silages as a substrate for biogas production. Landtechnik 2008, 63, 210-211, 246.

28. Weissbach, F.A. Simple method for the correction of fermentation losses measured in laboratory silos. In Proceedings of the XIVth International Silage Conference, Belfast, UK, 30 July 2005; Park, R.S., Strong, M.D., Eds.; Wageningen Academic Publishers: Wageningen, The Netherlands, 2005; p. 278.

29. Naumann, C.; Bassler, R. Methodenbuch des VDLUFA: Die chemische Untersuchung von Futtermitteln (Book of methods of VDLUFA: The chemical analysis of feeds), Volume III, Ergänzungslieferung [supplementary supply] 1993; VDLUFA Verlag: Darmstadt, Germany, 1976. (In German)

30. Committee for Requirement Standards of the Society of Nutrition Physiology. New Equations for Predicting Metabolizable Energy of Grass and Maize Products; DLG-Verlag: Frankfurt am Main, Germany, 2008; pp. 191-198.

31. Schmidt, L.; Weissbach, F.; Wernecke, K.D.; Hein, E. Erarbeitung von Parametern für die Vorhersage und Steuerung des Gärungsverlaufes bei der Grünfuttersilierung zur Sicherung einer hohen Silagequalität [Suitable Parameters to Predict and Control the Fermentation Process of Silages with High Quality]; Forschungsbericht der Akademie der Landwirtschaftswissenschaften der DDR: Rostock, Germany, 1971.

32. Weiss, K.; Kroschewski, B.; Auerbach, H. Effects of air exposure, temperature and additives on fermentation characteristics, yeast count, aerobic stability and volatile organic compounds in corn silage. J. Dairy Sci. 2016, 99, 8053-8069. [CrossRef] [PubMed]

33. Weiss, K.; Kaiser, E. Milchsäurebestimmung in Silageextrakten mit Hilfe der HPLC [Lactic acid determination in silage extracts by HPLC]. Das wirtschaftseigene Futter 1995, 41, 69-80.

34. Von Lengerken, J.; Zimmermann, K. Handbuch Futtermittelprüfung (Handbook Feed Evaluation), 1st ed.; Deutscher Landwirtschaftsverlag: Berlin, Germany, 1991; pp. 206-267.

35. ISO 15214. Microbiology of Food and Animal Feedingstuffs-Horizontal Method for the Enumeration of Mesophilic Lactic Acid Bacteria-Colony-Count Technique at $30^{\circ} \mathrm{C}$, 1st ed.; International Organization for Standardization: Geneva, Switzerland, 1998.

36. ISO 21527-1. Microbiology of Food and Animal Feeding Stuffs-Horizontal Method for the Enumeration of Yeasts and Moulds-Part 1: Colony Count Technique in Products with Water Activity Greater Than 0.95; International Organization for Standardization: Geneva, Switzerland, 2008.

37. Honig, H. Evaluation of aerobic stability. In Proceedings of the EUROBAC Conference, Uppsala, Sweden, 12-16 August 1986; Lindgren, S., Pettersson, K.L., Eds.; Swedish University of Agricultural Sciences: Uppsala, Sweden, 1990; pp. 76-82.

38. Tabacco, E.; Righi, F.; Quarantelli, A.; Borreani, G. Dry matter und nutritional losses during aerobic deterioration of corn and sorghum silages as influenced by different lactic acid bacteria inocula. J. Dairy Sci. 2011, 94, 1409-1419. [CrossRef] [PubMed]

39. Weissbach, F.; Honig, H. Über die Vorhersage und Steuerung des Gärungsverlaufs bei der Silierung von Grünfutter aus extensivem Anbau [Prediction and control of the fermentation process in silages made from extensively grown crops]. Landbauforsch. Völkenrode 1996, 46, 10-17.

40. Chen, Y.; Weinberg, Z.G. Changes during aerobic exposure of wheat silages. Anim. Feed Sci. Technol. 2009, 154, 76-82. [CrossRef]

41. Chulze, S.; Ramirez, M.L.; Farnochi, M.C.; Pascale, M.; Visconti, A.; March, G. Fusarium and fumonisin occurrence in Argentinian corn at different ear maturity stages. J. Agric. Food Chem. 1996, 44, 2797-2801. [CrossRef]

42. Matthäus, K.; Dänicke, S.; Vahjen, W.; Simon, O.; Wang, J.; Valenta, H.; Meyer, K.; Strumpf, A.; Ziesenib, H.; Flachowsky, G. Progression and mycotoxin and nutrient concentrations in wheat after inoculation with Fusarium culmorum. Arch. Anim. Nutr. 2004, 58, 19-35. [CrossRef]

43. Rooke, J.A.; Hatfield, R.D. Biochemistry of ensiling. In Silage Science and Technology; Agronomy 42; Buxton, D.R., Muck, R.E., Holmes, H.J., Eds.; American Society of Agronomy, Inc. Publishers: Madison, WI, USA, 2003; pp. 95-139.

44. Kung, L., Jr.; Shaver, R.D.; Grant, R.J.; Schmidt, R.J. Silage review: Interpretation of chemical, microbial and organoleptic components of silages. J. Dairy Sci. 2018, 101, 4020-4033. [CrossRef]

45. Oliveira, A.S.; Weinberg, Z.G.; Ogunade, I.M.; Cervantes, A.A.P.; Arriola, K.G.; Jiang, Y.; Kim, D.; Li, X.; Gonçalves, M.C.M.; Vyas, D.; et al. Meta-analysis of effects of inoculation with homofermentative and facultative heterofermentative lactic acid bacteria on silage fermentation, aerobic stability, and the performance of dairy cows. J. Dairy Sci. 2017, 100, 4587-4603. [CrossRef] 
46. Kleinschmit, D.H.; Kung, L., Jr. A meta-analysis of the effects of Lactobacillus buchneri on the fermentation and aerobic stability of corn and grass and small-grain silages. J. Dairy Sci. 2006, 89, 4005-4013. [CrossRef]

47. Auerbach, H.; Weiss, K.; Theobald, P. Additive type and composition affect fermentation pattern, yeast count, aerobic stability and formation of volatile organic compounds in whole-crop rye silage. In Proceedings of the XVIII International Silage Conference, Bonn, Germany, 24-26July 2018; Gerlach, K., Südekum, K.-H., Eds.; University of Bonn: Bonn, Germany, 2018; pp. 212-213.

48. Rabelo, C.H.S.; Härter, C.J.; da Silva Avila, C.L.; Reis, R.A. Meta-analysis of the effects of Lactobacillus plantarum and Lactobacillus buchneri on fermentation, chemical composition and aerobic stability of sugarcane silage. Grassl. Sci. 2019, 65, 3-12. [CrossRef]

49. Gomes, A.L.M.; Bolsson, D.C.; Jacovaci, F.A.; Nussio, L.G.; Jobim, C.C.; Daniel, J.L.P. Effects of light wilting and heterolactic inoculant on the formation of volatile organic compounds, fermentative losses and aerobic. stability of oat silage. Anim. Feed Sci. Technol. 2019, 247, 194-198. [CrossRef]

50. Oude-Elferink, S.J.W.H.; Krooneman, J.; Gotschal, J.C.; Spoelstra, S.F.; Faber, F.; Driehuis, F. Anaerobic degradation of lactic acid to acetic acid and 1,2-propandediol by Lactobacillus buchneri. Appl. Environ. Microbiol. 2001, 67, 125-132. [CrossRef]

51. Condon, M. Responses of lactic acid bacteria to oxygen. FEMS Microbiol. Rev. 1987, 46, 269-280. [CrossRef]

52. Krooneman, J.; Faber, F.; Alderkamp, A.C.; Oude-Elferink, S.J.H.W.; Driehuis, F.; Cleenwerck, I.; Swings, J.; Gottschal, J.C.; Vancanneyt, M. Lactobacillus diolivorans sp. nov., a 1,2-propanediol-degrading bacterium isolated from aerobically stable maize silage. Int. J. Syst. Evol. Microbiol. 2002, 52, 639-646. [CrossRef] [PubMed]

53. Zielińska, K.; Fabiszewska, A.; Świątek, M.; Szymanowska-Powałowska, D. Evaluation of the ability to metabolize 1,2-propanediol by heterofermentative bacteria of the genus Lactobacillus. Electronic J. Biotechnol. 2017, 26, 60-63. [CrossRef]

54. Auerbach, H.; Nadeau, E. Effects of storage conditions and additive type on fermentation quality, aerobic stability and nutritional value of grass-clover silage. In Proceedings of the XVIII International Silage Conference, Bonn, Germany, 24-26July 2018; Gerlach, K., Südekum, K.-H., Eds.; University of Bonn: Bonn, Germany, 2018; pp. 250-251.

55. Woolford, M.K. Microbiological screening of food preservatives, cold sterilants and specific antimicrobial antimicrobial agents as potential silage additives. J. Sci. Food Agric. 1975, 26, 229-237. [CrossRef]

56. Teller, R.S.; Schmidt, R.J.; Whitlow, L.W.; Kung, L., Jr. Effect of physical damage to ears of corn before harvest and treatment with various additives on the concentration of mycotoxins, silage fermentation, and aerobic stability of corn silage. J. Dairy Sci. 2012, 95, 1428-1436. [CrossRef]

57. Bernardes, T.F.; de Oliveira, I.L.; Lara, M.A.S.; Casagrande, D.R.; Avila, C.L.S.; Pereira, O.G. Effects of potassium sorbate and sodium benzoate at two application rates on fermentation and aerobic stability of maize silage. Grass Forage Sci. 2014, 70, 491-498. [CrossRef]

58. Kung, L., Jr.; Robinson, J.R.; Ranjit, N.K.; Chen, J.H.; Golt, C.M.; Pesek, J.D. Microbial populations, fermentation end-products, and aerobic stability of corn silage treated with ammonia or a propionic acid-based preservative. J. Dairy Sci. 2000, 83, 1479-1486. [CrossRef]

59. Schmidt, R.J.; Kung, L., Jr. The effects of Lactobacillus buchneri with or without a homolactic bacterium on the fermentation and aerobic stability of corn silages made at different locations. J. Dairy Sci. 2010, 93, 1616-1624. [CrossRef] [PubMed]

60. Auerbach, H.; Nadeau, E. Chemical additives for silages: When to use it and what are the options? In Proceedings of the VIth International Symposium on Forage Quality and Conservation, Piracicaba, Brazil, 7-8 November 2019; Nussio, L.G., da Silva, E.B., Oliveira, K.S., Gritti, V.C., Salvo, P.A.R., Salvati, G.G., de Sousa, D.O., Eds.; University of Sao Paulo: Piracicaba, Brazil, 2019; pp. 49-88.

61. Reich, L.J.; Kung, L., Jr. Effects of combining Lactobacillus buchneri 40788 with various lactic acid bacteria on the fermentation and aerobic stability of corn silage. Anim. Feed Sci. Technol. 2010, 159, 105-109. [CrossRef]

62. Weiss, K.; Kroschewski, B.; Auerbach, H. Formation of volatile organic compounds during the fermentation of maize as affected by sealing time and silage additive use. Arch. Anim. Nutr. 2020, 74, 150-163. [CrossRef] [PubMed]

63. Pahlow, G.; Muck, R.E.; Driehuis, F.; Oude-Elferink, S.J.W.E.; Spoelstra, S.F. Microbiology of ensiling. In Silage Science and Technology; Agronomy Series 42; Buxton, D.R., Muck, R.E., Holmes, H.J., Eds.; American Society of Agronomy, Inc. Publishers: Madison, WI, USA, 2003; pp. 31-93. 
64. Pitt, R.E.; Muck, R.E.; Pickering, N.B. A model of aerobic fungal growth in silage. 2. Aerobic stability. Grass Forage Sci. 1991, 46, 301-312. [CrossRef]

65. Adesogan, A.T.; Salawu, M.B.; Ross, A.B.; Davies, D.R.; Brooks, A.E. Effect of Lactobacillus buchneri, Lactobacillus fermentum, Leuconostoc mesenteroides inoculants, or a chemical additive on the fermentation, aerobic stability, and nutritive value of crimped wheat grains. J. Dairy Sci. 2003, 86, 1789-1796. [CrossRef]

66. Tüller, G.; Armbruster, A.; Wiedenmann, S.; Hänichen, T.; Schams, D.; Bauer, J. Occurrence of roquefortine C in silage-Toxicological relevance to sheep. J. Anim. Physiol. Anim. Nutr. 1998, 80, 246-249. [CrossRef]

67. Boysen, M.E.; Skuboe, P.; Frivad, J.; Rossen, L. Reclassification of the Penicillium roqueforti group into three species on the basis of molecular genetic and biochemical profile. Microbiology 1996, 142, 541-549. [CrossRef] [PubMed]

68. Pitt, R.J.; Hocking, A.D. The ecology of fungal food spoilage. In Fungi and Food Spoilage, 2nd ed.; Pitt, J.I., Hocking, A.D., Eds.; Academic Press: Sydney, NSW, Australia, 1997; pp. 3-12.

69. Tagni, E.K.; Pussemier, L.; Bastiaanse, H.; Haesaert, G.; Foucart, G.; van Hove, F. Presence of mycophenolic acid, roquefortine $\mathrm{C}$, citrinin and ochratoxin $\mathrm{A}$ in maize and grass silages supplied to dairy cattle in Belgium. J. Anim. Sci. Adv. 2013, 3, 598-612.

70. Müller, H.-M.; Amend, R. Formation and disappearance of mycophenolic acid, patulin, penicillic acid and PR Toxin in maize silage inoculated with Penicillium roqueforti. Arch. Anim. Nutr. 1997, 50, 213-225. [CrossRef]

71. Driehuis, F.; Spanjer, M.C.; Scholten, J.F.; te Griffel, M.C. Occurrence of mycotoxins in feedstuffs of dairy cows and estimation of total dietary intakes. J. Dairy Sci. 2008, 91, 4261-4271. [CrossRef]

72. Cavallarin, L.; Tabacco, E.; Antoniazzi, S.; Borreani, G. Aflatoxin accumulation in whole crop maize silage as a result of aerobic exposure. J. Sci. Food Agric. 2011, 91, 2419-2425. [CrossRef] [PubMed]

(C) 2020 by the authors. Licensee MDPI, Basel, Switzerland. This article is an open access article distributed under the terms and conditions of the Creative Commons Attribution (CC BY) license (http://creativecommons.org/licenses/by/4.0/). 